\title{
Assessment of Phytoviral Status of some New Plum Orchards Established in Iaşi County, Romania
}

\author{
Ioan ZAGRAI*, Luminița ZAGRAI, Georgeta GUZU \\ Fruit Research \& Development Station Bistrița 3 Drumul Dumitrei Nou, Bistriţa, 420127, Romania \\ *corresponding author: izagrai@yahoo.com
}

BulletinUASVM Horticulture 77(2) / 2020

Print ISSN 1843-5254, Electronic ISSN 1843-5394

DOI:10.15835/buasvmcn-hort: 2020.0037

\begin{abstract}
Four young plum orchards from Iaşi county, two of these established by using propagated material in Romania, and the other two with material from Austria, Czech Republic and Netherlands, were surveyed by visual observation of viral symptoms. Then, trees were sampled and tested for the presence of six viruses (PPV, PDV, PNRSV, ACLSV, ApMV and MLRSV) by serologic assays. A high rate of PPV infection (78\% and 79\%, respectively) was determinated in the two orchards established with planting material propagated in Romania, and a rate of $5 \%$ PDV infection was found in one of them. A rate of 2.5\% PPV infection was determined in the orchard established with propagated material in Austria and Czech Republic, and no PPV infected tree was found in the orchard set up with material propagated in Netherlands. The infections with PNRSV, ACLSV, ApMV and MLRSV were not detected in the four orchards surveyed.
\end{abstract}

Keywords: DAS-ELISA, plum, propagation material, survey, viruses

\section{Introduction}

The management of the control of virus diseases represents a priority in any strategy of diminishing the quantitative and qualitative losses of the fruit yield. In case of infection with viruses, trees can no longer be treated in the orchard. Therefore, mitigation measures are aimed mainly to prevent virus infections by all possible means (use of resistant varieties - if any, use of virus-free planting material, placement of new orchards as far away from sources of infection, treatments against virus vectors, etc.). However, there are often situations when the virus infection overcome these prevention measures and escape in the new orchards. In spite of European regulatory and EPPO standards requested for plant certification, there are cases with deficiencies in its implementation. In addition, free movement of propagating material within the European Union increases the risk of the spread of viruses/viral strains in new areas. Thus, new virus outbreaks may occur and can create serious problems in new orchards and, sometimes, even compromise the investment. Once a virus infection accidentally occurs in the young orchards, removing of the infected trees remain the main measure for limiting the virus spreading. Therefore, early identification of infections in new orchards can sometimes be plum tree life-saving. Thus, the monitoring of viruses in the new orchards, followed by suitable measures for limiting their spreading depending on the specific phytosanitary situation observed, may reduce the damage caused by viruses.

In most European countries, including Romania, plum is highly affected by Plum pox virus (PPV), the causal agent of Sharka, knows as the most devasting virus disease that affect stone fruits (Barba et al., 2011; Cambra et al., 2006; 


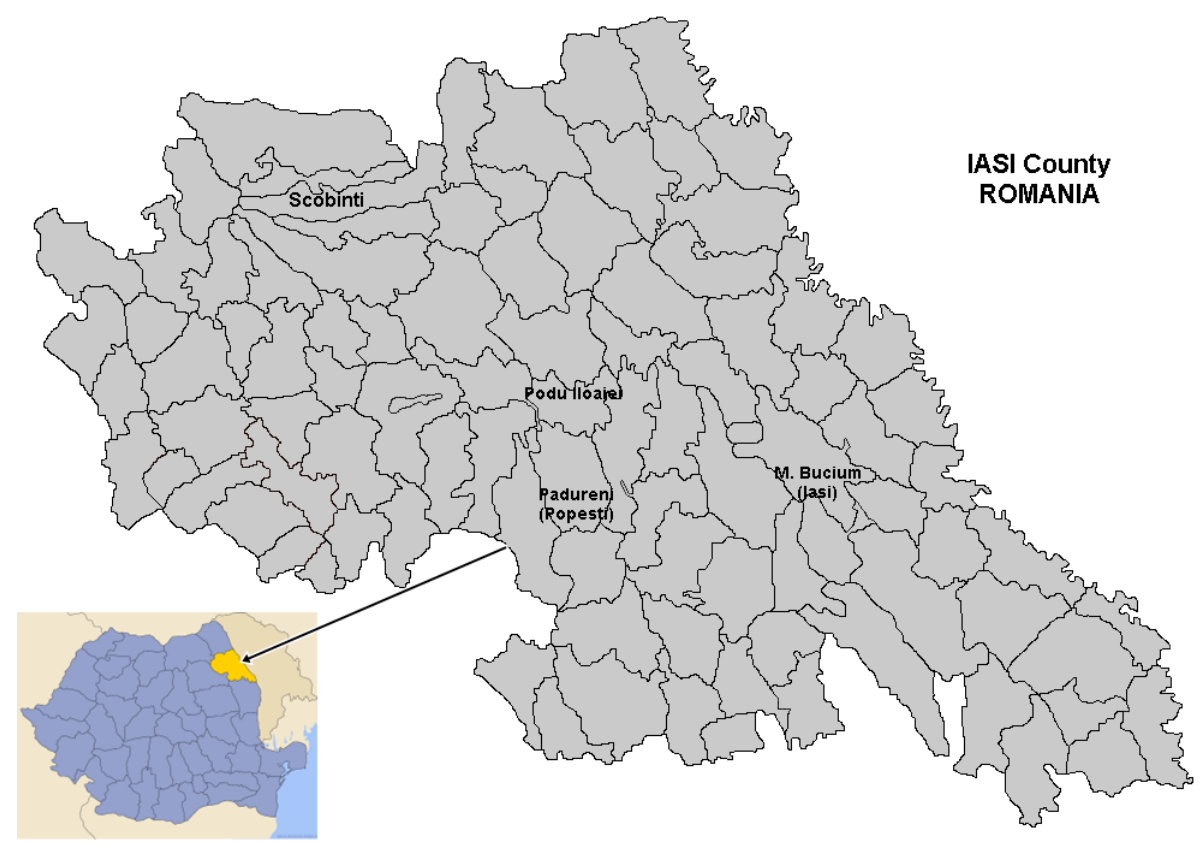

Figure 1. Location of plum orchards monitored from Iaşi county, Romania

Zagrai et al., 2010). Other viruses such us Prune dwarf (PDV), Prunus necrotic ring spot (PNRSV), Apple chlorotic leaf spot (ACLSV), Apple mosaic (ApMV) and Mirobolan latent ringspot (MLRSV) also might cause direct or indirect damages, as growth reduction, loss of plant vigour, a decrease of quality values, and overall with a negative effect on productive parameters of the crops (Hadidi and Barba, 2011).

Plum is the dominant fruit species in Romania (FAOSTAT, 2018) and hence its economic importance. New plum orchards were established in the last years by using planting material produced both in Romania and in different European countries. This allowed us to get information about initial virus status of planting material by assessing the incidence of the viruses in the young orchards.

\section{Materials and methods}

Four young plum orchards from Iasi county were the subject of the survey in this study. Two of these were established by using propagated material in Romania, and the other two with material from Austria, Czech Republic and Netherlands. Two blocks with a total of 200 trees (each block of 100 trees) from each orchard were monitored by visual observation of viral symptoms development. The surveys were mainly focused on typical PPV symptoms on leaves that allowed getting a preliminary evaluation on the incidence of PPV based on the visual observations. Then, ten trees from each block were sampled for virus diagnosis by serological assays, as follows: when PPV incidence based on visual observations was lower than $10 \%$, one symptomatic and nine asymptomatic trees were randomly sampled. When the visual incidence was between 10 and $20 \%$, two symptomatic and eight asymptomatic trees were sampled; and so on, so that when PPV visual incidence was between $90-100 \%$, ten symptomatic trees were sampled. In the case of no symptomatic trees, ten trees were randomly sampled from each block. Because PPV-M, known as the most PPV epidemic strain, was not reported so far in Romania (Zagrai et al., 2010), additional samples with typical PPV symptoms were collected from young orchards established with planting material from abroad to check its potential overcoming of the borders (data not shown). For subsequent viruses diagnosis by serological assays a minimum of ten leaves per tree were randomly collected throughout the canopy. In PPV symptomatic trees, only symptomatic leaves were collected. If symptoms were limited to particular branches, leaves were only sampled from symptomatic branches. 
Table 1. Virus infections based on visual observation and DAS-ELISA assay

\begin{tabular}{|c|c|c|c|c|c|c|c|c|c|}
\hline \multirow{2}{*}{$\begin{array}{l}\text { Orchard } \\
\text { location }\end{array}$} & \multirow{2}{*}{$\begin{array}{l}\text { Provenance of } \\
\text { plant material }\end{array}$} & \multirow{2}{*}{$\begin{array}{l}\text { Visual } \\
\text { rate of } \\
\text { PPV (\%) }\end{array}$} & \multirow{2}{*}{$\begin{array}{c}\text { No. of symptomatic } \\
\text { samples/total } \\
\text { no. of collected } \\
\text { samples }\end{array}$} & \multicolumn{6}{|c|}{$\begin{array}{c}\text { DAS-ELISA results } \\
\mathrm{OD}=405 \mathrm{~nm}\end{array}$} \\
\hline & & & & PPV & PDV & PNRSV & ACLSV & ApMV & MLRSV \\
\hline Scobinti & Romania & 79.0 & $16 / 20$ & 16 & 0 & 0 & 0 & 0 & 0 \\
\hline M. Bucium & Romania & 78.0 & $16 / 20$ & 15 & 1 & 0 & 0 & 0 & 0 \\
\hline Podul Iloaiei & $\begin{array}{l}\text { Austria } \\
\text { and Czech } \\
\text { Republic }\end{array}$ & 2.5 & $2 / 20$ & 2 & 0 & 0 & 0 & 0 & 0 \\
\hline $\begin{array}{l}\text { Padureni- } \\
\text { Popesti }\end{array}$ & Netherlands & 0.0 & $0 / 20$ & 0 & 0 & 0 & 0 & 0 & 0 \\
\hline Total & & & $34 / 80$ & 33 & 1 & 0 & 0 & 0 & 0 \\
\hline
\end{tabular}

A total of eighty samples (twenty from each orchard) were subjected to viruses diagnosis. Serological tests were performed by Double Antibody Sandwich - Enzyme Linked Immunosorbent Assay (DAS-ELISA) (Clark and Adams, 1977) using a commercial polyclonal antiserum to PPV, PDV, PNRSV, ACLSV, ApMV (Bioreba, Switzerland), and MLRSV (Sediag, France) according to the manufacturer's instructions. Absorbance values were measured at $405 \mathrm{~nm}$ after $1 \mathrm{~h}$ substrate hydrolysis. Samples were considered positive if their absorbance values were more than twice those of the negative control. Then, a rate of infection was established for each virus.

The nearby plum orchards $(1-200 \mathrm{~m})$ were visually checked and has been established the incidence of PPV based on the observed symptoms in order to check the potential presence of nearby outbreaks/sources of infection.

\section{Results and discussion}

Four young plum orchards from Iasi county were identified in different location: Scobinti, M. Bucium, Podul Iloaiei, and Padureni-Popesti (Fig.1).

Results of surveys for the presence of viruses by visual monitoring and serological assays are showed in the Table 1 . Important to mentioned that DAS-ELISA results reveled that all symptomatic samples confirm the presence of viruses, thirtythree being infected by PPV and one by PDV. A PDV infection was found in only one orchard.

Plum orchards established by using plant material propagated in Romania (orchards from Scobinti and M. Bucium). In both plum orchards, the results obtained by serological assays consistently confirmed the observations based on PPV symptoms development. Therefore, in such cases the rate of PPV established by visual observation is appropriate because of higher number of trees monitored. Thus, the results revealed that both plum orchards are massively infected with Plum pox virus. The high rate of PPV infection $(79 \%$ and $78 \%$, respectively) correlated with the young age of the orchards, and a virus infection spread throughout the canopy in most of the trees, suggests that most part of the planting material has come infected from the nursery. This is also suported by the fact that an external source of the inoculum was observed at a distance of over 200 $\mathrm{m}$, and it was represented only by isolated trees in family gardens that could not led to such critical situation. These orchards represent themself a source of PPV for new potential orchards set up around. Also, a rate of 5\% PDV infection was found in one of them (M. Bucium location). This high rate of PPV infection can determine the removal of a lot of infected plum trees with the main aim to reduce the spread of PPV but with negative effects regarding the plum production. This radical measure is not in agreement with the orchard owners' management strategies because of the loss of financial support from governmental authorities.

Plum orchards established by using plant material propagated in Austria and Czech Republic. Results on plum orchard from Podu Iloaiei showed a very good phytovirotic status. Plum pox virus was present just sporadically in the orchard (2.5\% incidence). Infections are noticed only on 
a few shoots which suggests that the propagated material was virus free at the time of planting. New infections in the orchard were most likely caused by the presence of scattered trees in the vicinity of the orchard that have widespread PPV infections and that have facilitated the transmission of the virus in conditions where they have not received treatments to control aphid vectors. The recommendation for this orchard is to remove PPV-infected trees as soon as possible from inside the orchard and replace infected trees with certified 'virus-free' plant material from the same nursery. Also, identifying of some solutions to eliminate the source of PPV infection from the vicinity of the orchard, given that they belong to other owners and a directly action is not possible. Visual monitoring of 2-3 times during vegetative periods and removal of PPV-infected trees in conjunction with treatments against aphid vectors represent important measures at the farmer disposal to keep under control PPV from this orchard.

Plum orchards established by using plant material propagated in Netherlands. Results on plum orchard from Padureni-Popesti revealed an excellent phytosanitary status. The orchard has a very good location, with great distances from potential sources of virus infection. No other plum orchard or wild relatives scattered at the distance of min $500 \mathrm{~m}$ from the orchard were found. No symptom suggesting a possible virus infection was observed within the plum orchard and DASELISA assays confirmed the absence of any viral infections.

Overall, the visual observations correlated with DAS-ELISA results revealed a high rate of PPV infection in the two orchards established with planting material propagated in Romania. Also, PDV infection was sporadically detected in one of the orchard. At the opposite, the situation of virus infection in the other two orchards established by using planting material propagated in Austria, Czech Republic and Netherlands was completely different. Thus, only a few trees with particular shoots with PPV infection were identified in the orchard established with propagated material in Austria and Czech Republic that suggests a viral infection occurred after planting. No PPV infected tree was found in the orchard set up with material propagated in Netherlands. No other virus infections were detected in the four orchards surveyed.

\section{Conclusions}

The results obtained in this survey revealed a critical situation regarding PPV infection of the two orchards established with propagated material in Romania. This situation raises questions on the certification of planting material at the two suppliers. At the opposite, the phytoviral status of the other two orchards established with planting material produced in Austria, Czech Republic and Netherlands was very good.

Acknowledgments. This work was supported by Romanian Ministry of Agriculture, contract ADER 7.3.13 / 2019.

\section{References}

1. Barba M, Hadidi A, Candresse T, Cambra M (2011). Plum pox virus. In A Hadidi (Ed.), Virus and Virus-Like diseases of Pome and Stone Fruits. (pp. 185-197). St. Paul, Minnesota: The American Phytopathologycal Society.

2. Cambra M, Capote N, Myrta A, Llacer G (2006). Plum pox virus and the estimated costs associated with sharka disease. EPPO Bull. 36: 202-204.

3. Clark MF, Adams AN (1977). Characteristic of the microplate method of enzyme linked immunosorbent assay (ELISA) for detection of plant viruses. J. Gen. Virology 34: 475-483.

4. Hadidi A, Barba M (2011). Economic impact of pome and stone fruit viruses and viroids. In A. Hadidi (Ed.), Virus and Virus-Like diseases of Pome and Stone Fruits. (pp. 1-7). St. Paul, Minnesota: The American Phytopathologycal Society.

5. Zagrai I, Zagrai L, Kelemen B, Petricele I, Pamfil D, Popescu O, Preda P, Briciu A (2010). Typing and distribution of Plum pox virus isolates in Romania. Julius-Kuhn-Archiv, 427: 342-346.

6. FAOSTAT, 2018. http://www.fao.org/faostat/en/\#data/ $\mathrm{QC}$ 